\title{
Required Capabilities of a High-Explosive Projectile for Active Protection Systems
}

\author{
Jovica Bogdanov ${ }^{1)}$ \\ Anas Chabane ${ }^{1)}$
}

\begin{abstract}
Concept of an active protection system on combat vehicles with high-explosive fragmentation interceptor projectile is presented in this paper. Development process and characteristics of the active protection system are highly dependent on performance characteristics of an interceptor projectile. The interceptor projectile generating frontal spray of steel spherical fragments was considered. The research on design features of contemporary rocket-propelled anti-tank projectiles was done in order to define required capabilities of the projectile for active protection systems. Vulnerability of an anti-tank projectile was analyzed according to its dimensions and design of main subsystems. Representative models of different types of anti-tank projectiles were considered for vulnerability assessment. Results of minimal fragment number density and minimal impact velocity are presented and the most significant conclusions are made.
\end{abstract}

Key words: high-explosive projectile, detonation, fragments, active protection systems.

\section{List of abbreviations and acronyms}

APS - active protection system;

AT - anti-tank;

ATGM - anti-tank guided missile;

EM - energetic material;

ERA - explosive reactive armor;

HE - high-explosive;

HEAT - high-explosive anti-tank;

HMX - octogen, 1,3,5,7-tetranitro-1,3,5,7-terazoctane;

LAW - light anti-tank weapon;

RPG - rocket propelled grenade;

TNT - trinitrotoluene, 2-methyl-1,3,5-trinitrobezene.

\section{Introduction}

$\mathrm{P}$ ROTECTION is a key element of survivability of a combat system. Traditionally, protection of combat systems is based on passive protection technologies, usually referred to as "ballistic protection" or simply "armor". Such protection is required to withstand or mitigate the effect of an enemy weapon system. Yet, materials for passive protection are very weight demanding, even when the most advanced technologies are used. High levels of protection can be achieved on combat systems with very high weight only, such as combat ships, main battle tanks and other heavy armored vehicles.

Reactive and active protection technologies are intended to provide high level of protection while maintaining limited weight of a combat system. Recent developments of land combat systems evidently show that hybrid protection is mainly used, where different passive, reactive and active protection subsystems are integrated. Also, that approach is used for protection upgrades in most combat vehicle modernization programs. Modern reactive protection technologies, like explosive reactive armor (ERA), can be very efficient against mass-produced light anti-tank (AT) weapon systems with effect based on shaped charge technology (High Explosive Anti-Tank, HEAT). It should be noted that most ERAs can only be used on combat systems with high level of passive protection, which significantly limits their potential use. Because of weight limitations, unarmored or light combat vehicles have low level of passive protection which cannot fulfill requirements for safe implementation of ERA.

Significant efforts have been made in research and development of active protection systems (APS) [1,2]. Their integration on different land combat platforms is especially challenging, mainly due to mass and cost limitations. In the last decade many reports have shown that at least a couple models of APSs were operational in military forces. This is a consequence of significant achievements in electronics and computer technology. But, their function is based on explosion effects. Primarily, safety limitations should be considered thoroughly [3-5]. Also, their performance can be precisely determined using high-explosive projectile design methods [6, 7], published results of similar research [8-12] and principles of explosion physics [13-16].

\section{Active protection systems with high-explosive interceptor projectiles}

Active protection systems can be seen as the best choice for efficient protection of a wide range of combat systems against AT weapons, and is probably the only one for vehicles with very light armor.

Subsystems of APS are performing following main tasks:

1. scanning the surrounding space for approaching projectiles,

\footnotetext{
1) University of Defense in Belgrade, Military Academy, Veljka Lukića Kurjaka 33, 11042 Belgrade, SERBIA

Correspondence to: Jovica Bogdanov; e-mail: jovica.bogdanov@va.mod.gov.rs
} 
2. detecting and tracking all possible threats,

3. analyzing trajectory of a possible threat, and

4. initiating appropriate countermeasures against the confirmed threat,

Capabilities of an APS depend on a type of interaction between the countermeasure and the threat. There are several different types of countermeasures used, that directly imply capabilities of an APS. Some systems use a single or a combination of jamming countermeasures only. That approach can be successful against anti-tank guided missiles (ATGM). But, overall effectiveness and flexibility is significantly better if an APS is also capable of a significant physical damage or destruction of a threat. Effects of such countermeasures are based on high-explosive subsystem that produces air blast wave or high velocity fragments. Also, different types of high-explosive subsystems are used in modern APS, according to the:

- type of generated effect (air shock wave, lateral or frontal spray of fragments, or a combination of the mentioned effects), and

- the position of the subsystem at the moment of interaction (HE charges attached to a combat system or interceptor projectiles launched towards the threat, Fig.1).
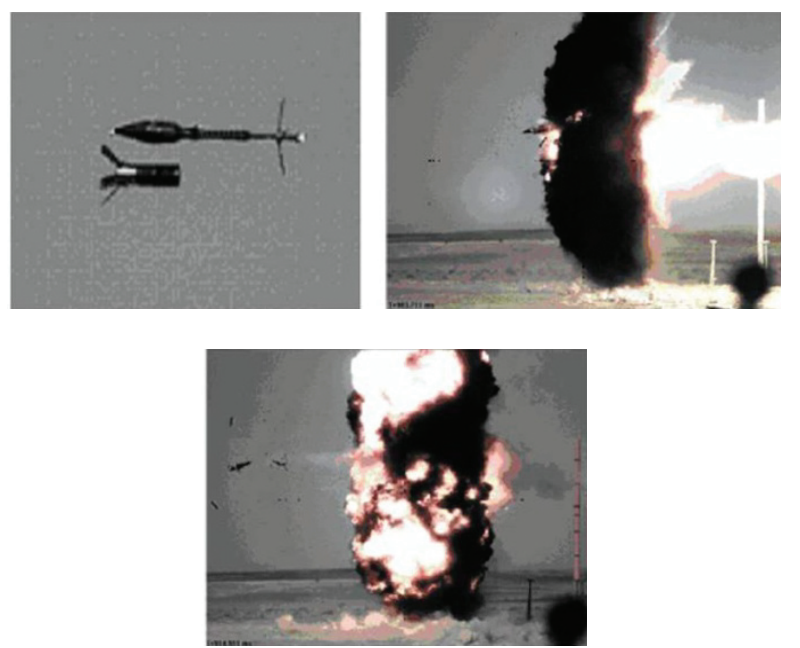

Figure 1. Effect of "Iron Fist LD" APS interceptor projectile against AT rocket propelled grenade [1]

Function of an APS with HE interceptor projectiles can be divided into following phases:

1. detection of the threat (incoming AT missile) at distance $x_{d}$ from a combat system,

2. analysis of the threat and preparation of the appropriate countermeasure during time period $t_{\text {prep}}$,

3. launching the interceptor projectile with initial velocity $v_{p}$,

4. explosion of the interceptor at distance $x_{\mathrm{p}}$ from the combat system, that generates appropriate effects (f.e. fragments with velocity $v_{\mathrm{f}}$ and air shock wave), and

5. interaction of countermeasure's effects with a threat at distance $x_{\mathrm{r}}$ from a combat system.

Since threat detection distance is limited, launched countermeasures inherently have longer reaction time and are not effective against very fast flying threats. According to the published data, the most APS for combat vehicles are capable of reliable detection and tracking of an incoming AT projectile at distances 50-100 m [1,2]. Simultaneously, the effects of a HE subsystem's explosion will interact with the protected combat system and compromise its safety. Since launched interceptor projectiles are initiated at a certain distance from the combat system, where the explosion effects are significantly mitigated, thus safety problems are of less concern.

Interceptor projectiles that generate a frontal spray of fragments have been chosen in this research (Fig.2). In that case, the interceptors and incoming AT projectiles have nearcolliding trajectories with following positive characteristics:

- damage effects are significantly increased, since velocities of both projectiles are being summed,

- since fragments are always propelled in direction opposite to the combat system and near-by friendly forces, so high level of safety can be achieved,

- safety considerations due to blast effect can be assessed by correctly defined minimal distance between the combat system and the point of interceptor's explosion $x_{\mathrm{p}}$.

- for appropriately launched interceptor projectile, spray of fragments is generated in front of incoming projectile, so fragment hit probability is less prone due to small estimation errors of incoming projectile's position and velocity,

- zone of a blast effect is also generated in front of the incoming projectile, so interaction with air shock wave is imminent, causing secondary damage or deflection of trajectory.

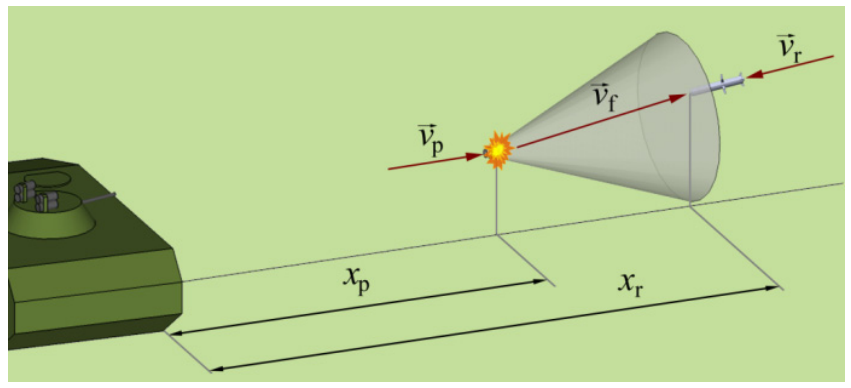

Figure 2. Interaction of the interceptor projectile and the incoming missile

In such case, for small angles between trajectories of interceptor projectile and incoming missile, time periods between moments of threat detection and interaction of countermeasure with the threat can be written as:

$$
\begin{gathered}
t_{\mathrm{r}}=\frac{x_{\mathrm{d}}-x_{\mathrm{r}}}{v_{\mathrm{r}}} \\
t_{\mathrm{p}}=t_{\text {prep }}+\frac{x_{\mathrm{p}}}{v_{\mathrm{p}}}+\frac{x_{\mathrm{f}}}{v_{\mathrm{f}}}
\end{gathered}
$$

For given detection distance, a successful interaction will occur if a reaction time of the APS $t_{\mathrm{p}}$ is shorter or equal to time of flight of the incoming missile $\left(t_{\mathrm{p}} \leq t_{\mathrm{r}}\right)$. Initial velocities of modern RPGs and ATGMs are up to $250 \mathrm{~m} / \mathrm{s}$ and $400 \mathrm{~m} / \mathrm{s}$, respectively. For detection distances $x_{\mathrm{d}}$ between 50 and $100 \mathrm{~m}$, their flight time to the distance $x_{\mathrm{r}}$ is between 87 and $340 \mathrm{~ms}$. Velocity of fragments is usually higher than $1000 \mathrm{~m} / \mathrm{s}$, so on short distances $\left(x_{\mathrm{r}}-x_{\mathrm{p}} \leq 5 \mathrm{~m}\right)$ they are dispersed in a couple of ms. Also, very short preparation time $t_{\text {prep }}$ can be achieved using modern electronics. According to that, successful interception of AT missiles will occur if interceptor projectiles are launched at distances $x_{\mathrm{p}}$ up to $15 \mathrm{~m}$ with minimum initial velocity $175 \mathrm{~m} / \mathrm{s}$. At those distances air shock wave generated by air-burst of explosive charge weighting up to $300 \mathrm{~g}$ is below temporary hearing loss threshold $[3,4]$.

Success of the interception depends on the probabilities of hit and damage also. For practical reasons, appropriate simplifications of the problem will be used. Interceptor 
projectile has spherical steel preformed fragments, thus avoiding problem of mass and shape distribution occurring during natural fragmentation. Also, fragments of other shapes have greater drag coefficient $C_{x}$ than spherical fragments. It is found to be bellow 0.95 at velocities above 3 Mach [5-6] and 0.97 for explosively deformed steel spheres [7]. Hit probability is determined by the fragment number density $\rho_{\mathrm{f}}$ at the target area projected on a plane which is normal to the trajectories of fragments:

$$
\rho_{\mathrm{f}}=\frac{N_{\mathrm{f}}}{A_{\mathrm{f}}}
$$

where $N_{\mathrm{f}}$ is total number of fragments and $A_{\mathrm{f}}$ is total area of the fragment dispersion. If uniform distribution of fragments can be assumed, then hit probability is in direct correlation with the target area $A_{\mathrm{r}}$. For given fragment number density $\rho_{\mathrm{f}}$, target will be certainly hit with at least one fragment if:

$$
A_{\mathrm{r}} \geq \frac{1}{\rho_{\mathrm{f}}}
$$

Damage probability directly depends on kinetic energy of a fragment, thus its mass $m_{\mathrm{f}}$, surface area $A_{\mathrm{f}}$ normal to its trajectory and velocity $v_{\mathrm{f}}$ at the moment of impact. Also, impact angle $\Theta$ should be considered also. Impact of a fragment from the interceptor projectile can induce one of the following damages to the threat (incoming missile):

- every impact to the contact-detecting subsystem of the fuze system will certainly induce an initiation of a warhead;

- perforations of outer parts of the warhead can induce severe and critical damage, causing its premature detonation or failure of proper function (fragment impact induced detonation of EM, improper jet formation due to shaped charge damage, failure of the fuze system due to short-cutting of electrical components or electronics failure etc.);

- an impact to a rocket motor of an ATGM can induce severe declination of its trajectory or even its explosion;

- impulse of the fragments and shock wave will certainly induce appropriate declination of the projectile's trajectory, causing the near-miss or improper impact angle.

\section{Vulnerability of anti-tank missiles}

In this analysis, it is assumed that vulnerability of an AT missile depends on:

- areas of its exposed surfaces $A_{\mathrm{r}}$ to effects of the interceptor projectile and

- design characteristics of its subsystems.

Since RPGs and ATGMs have different shapes and dimensions, exposed areas of five missiles will be analyzed, that are representing different types of AT projectiles:

1. $66 \mathrm{~mm}$ HEAT rocket for M72 LAW (light shoulder-fired rocket launcher),

2. $85 \mathrm{~mm}$ HEAT rocket propelled grenade PG-7V for RPG7 (shoulder-fired RPG launcher),

3. $90 \mathrm{~mm}$ HEAT rocket for C90-CR-RB (M3) (medium shoulder-fired rocket launcher),

4. $125 \mathrm{~mm}$ HEAT ATGM 9M14 for 9K11 "Malyutka" $\left(1^{\text {st }}\right.$ generation ATGM), and

5. $127 \mathrm{~mm}$ HEAT ATGM for ( ${ }^{\text {rd }}$ generation ATGM).

First, 3D models of projectiles were made according to their dimensions. Exposed area of a missile significantly depends on an interception angle $\Theta_{0}$ (Fig.3). Using 3D models of AT projectiles, areas of exposed surfaces of considered missiles were determined for interception angles between $0^{\circ}$ and $60^{\circ}$. Interception angles above $60^{\circ}$ are possible for interceptor projectiles with lateral spray of fragments, so for chosen type of interceptor projectile are not considered.

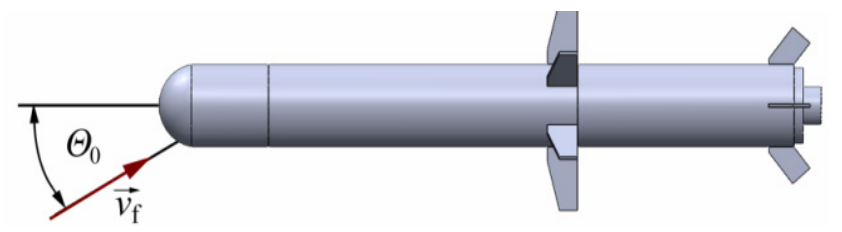

Figure 3. Interception angle between fragments and a missile

For ATGMs, two exposed areas are being analyzed: warhead section $A_{\mathrm{r}, 1}$, and propulsion section $A_{\mathrm{r}, 2}$. Propulsion section has a significant effect on a ATGM's proper function. Besides subsystems for propulsion purposes, these sections has many complex subsystems needed for guidance and overall functioning of a missile (movable fins or nozzles for steering, gyroscopes for orientation, subsystems for communication between a missile and a launching platform, electrical power sources etc.). Hits in such sections closely-packed with a large number of important subsystems can make severe damage. For the same reasons, frontal guidance section of ATGM for FGM-148 "Javelin" was included as a part of the warhead [17]. Values are presented in Tables 1 and 2, and their shapes are shown in Figures 4 and 5.

Table 1. Areas of exposed surfaces of warheads of AT rocket-propelled projectiles

\begin{tabular}{|c|c|c|c|c|c|c|c||}
\hline \multirow{2}{*}{$\begin{array}{c}\text { AT weapon } \\
\text { system }\end{array}$} & \multicolumn{6}{|c|}{ Area of exposed surface $A_{\mathrm{r}, 1}$ for different interception } \\
\cline { 2 - 8 } & $0^{\circ}$ & $10^{\circ}$ & $20^{\circ}$ & $30^{\circ}$ & $40^{\circ}$ & $50^{\circ}$ & $60^{\circ}$ \\
\hline \hline M72 LAW & 0.3421 & 0.4171 & 0.5386 & 0.7487 & 0.9050 & 1.0417 & 1.1511 \\
\hline RPG-7 & 0.5675 & 0.5964 & 0.7489 & 0.9858 & 1.2353 & 1.4311 & 1.5887 \\
\hline C90-CR-RB & 0.6482 & 0.7453 & 1.0363 & 1.3625 & 1.6471 & 1.8885 & 2.0789 \\
\hline $\begin{array}{c}\text { 9K11 } \\
\text { "Malyutka" }\end{array}$ & 1.2023 & 1.6494 & 2.0430 & 2.4979 & 2.9000 & 3.2085 & 3.4015 \\
\hline $\begin{array}{c}\text { FGM-148 } \\
\text { "Javelin" }\end{array}$ & 1.5593 & 3.1216 & 4.6538 & 6.0561 & 7.2856 & 8.3010 & 9.0745 \\
\hline \hline
\end{tabular}

Table 2. Areas of exposed surfaces of propulsion sections of ATGMs

\begin{tabular}{|c|c|c|c|c|c|c|c|}
\hline \hline \multirow{2}{*}{$\begin{array}{c}\text { AT weapon } \\
\text { system }\end{array}$} & \multicolumn{7}{|c|}{ Area of exposed surface $A_{\mathrm{r}, 2}$ for different interception } \\
angle $\Theta_{0}, \mathrm{dm}^{2}$
\end{tabular}

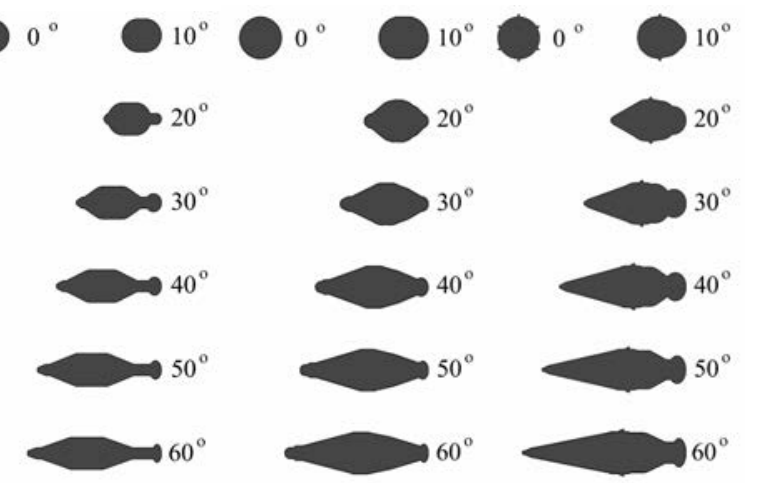

Figure 4. Exposed surfaces of HEAT warheads of AT rocket propelled projectiles 

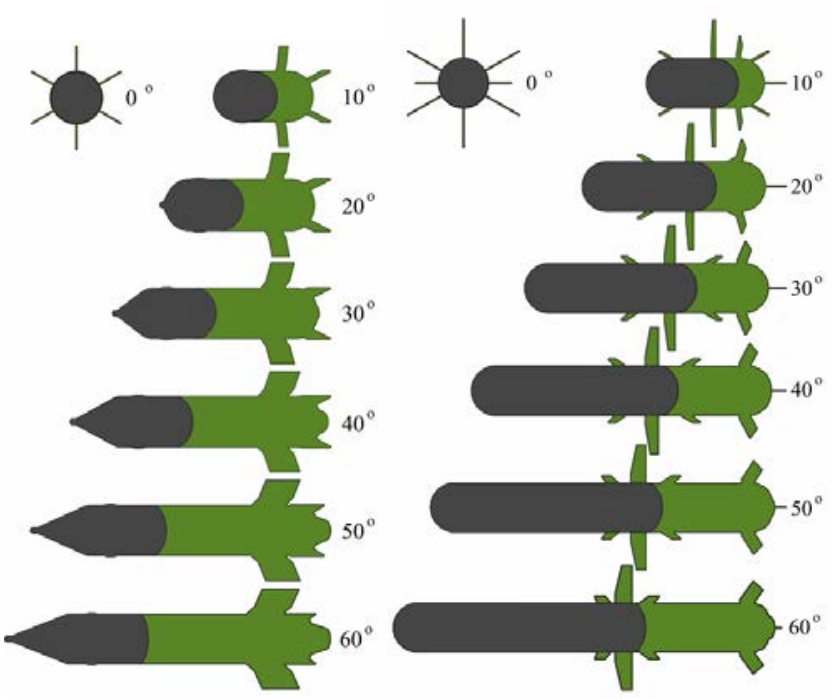

Figure 5. Exposed surfaces of AT guided missiles

Further analysis of design of AT missiles is done in order to define minimum criteria for fragments that will be able to induce severe damage to a missile's warhead. Since each model has its own design features, two characteristic types of HEAT warheads are defined and analyzed (Table 3):

- RPG-type of HEAT warhead with two frontal cones (windshield and electric contact cone), shaped charge cone and cylindrical warhead body (Fig.6) and

- ATGM-type of HEAT warhead with one frontal cone (windshield), shaped charge cone and cylindrical warhead body (Fig.7).

Table 3. Dimensions of different design types of HEAT warheads

\begin{tabular}{|c|c|c|c|c|c|c|c|c||}
\hline $\begin{array}{c}\text { Type of war- } \\
\text { head }\end{array}$ & $\delta_{1} \cdot \mathrm{mm}$ & $\beta_{1} \cdot^{\circ}$ & $\delta_{2} \cdot \mathrm{mm}$ & $\beta_{2} .^{\circ}$ & $\delta_{3} \cdot \mathrm{mm}$ & $\beta_{3 .}{ }^{\circ}$ & $\delta_{4 .} \mathrm{mm}$ & $\beta_{4 .}{ }^{\circ}$ \\
\hline \hline RPG-type & 0.7 & 14 & 0.7 & 14 & 2.0 & 30 & 1.0 & 0 \\
\hline ATGM-type & 1.6 & 17 & - & - & 2.0 & 25 & 2.0 & 0 \\
\hline
\end{tabular}

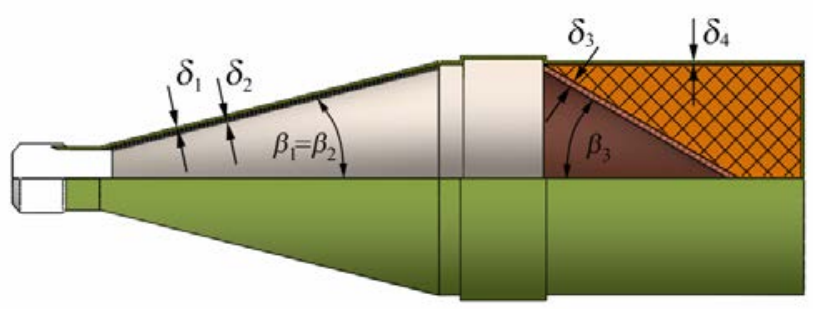

Figure 6. Dimensions of RPG-type HEAT warhead

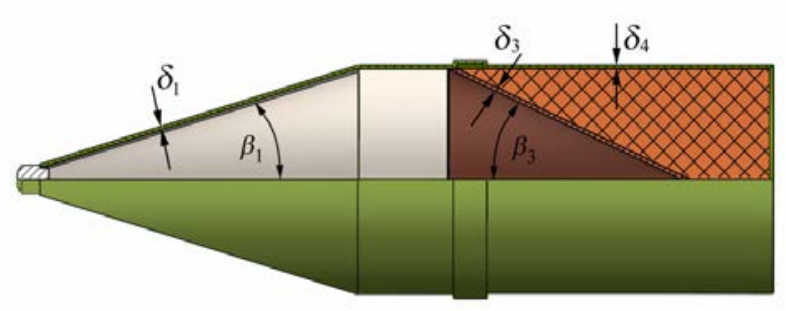

Figure 7. Dimensions of ATGM-type HEAT warhead

Two cases of perforation were considered: through frontal parts, perforating windshield, contact cone and opposite side of copper cone, and laterally, perforating warhead body only. In both types of warheads, it was chosen that shaped charge cones are made of copper and all other parts of aluminum alloy 2024-T3. For defined warheads and for the interception angle, minimal value of fragment impact velocity $v_{\text {f.min }}$ was determined according to changes of velocities $\Delta v_{\mathrm{i}}$ due to penetration through parts of a warhead. Since there are very short distances between parts of a warhead, fragment velocity loss due to the drag is neglected. Fragment mass loss and deflection of its trajectory are neglected also. After successful perforation of an $i^{\text {th }}$ part, fragment has residual velocity $v_{\text {res.i }}$ and with that velocity impacts next part $(i+1)$. Residual velocities are calculated using "Thor" equations [9-12]:

$$
\begin{gathered}
\Delta v_{\mathrm{i}}=\frac{10^{c}\left(\delta_{i} \cdot S_{\mathrm{f}}\right)^{\alpha} \cdot m_{f}^{\beta} \cdot v_{\mathrm{f}, \mathrm{i}}^{\lambda}}{\left(\cos \theta_{\mathrm{i}}\right)^{\gamma_{1}}} \\
v_{\text {res }, \mathrm{i}}=v_{\mathrm{f}, \mathrm{i}+1}=v_{\mathrm{f}, \mathrm{i}}-\Delta v_{\mathrm{i}}
\end{gathered}
$$

where $\Theta_{\mathrm{i}}$ is $i^{\text {th }}$ impact angle of a fragment in radians, $m_{\mathrm{f}}$ is a fragment mass in grains ( 1 grain $=0.064799 \mathrm{~g})$, and $c . \alpha . \beta . \gamma$ and $\lambda$ are empirical coefficients that represent different materials of warhead parts (Table 4). All velocities are expressed in fps $(1 \mathrm{fps}=0.3048 \mathrm{~m} / \mathrm{s})$.

Impact angles $\Theta_{\mathrm{i}}$ are calculated according to the interception angle $\Theta_{0}$ and angles $\beta_{\mathrm{i}}$ (Figures 9 and 10) using following equation:

$$
\theta_{\mathrm{i}}=\frac{\pi}{2}-\theta_{0}-\beta_{\mathrm{i}}
$$

It should be noted that curvature of conical and cylindrical surfaces causes significant increase of fragment impact angle at upper and lower border regions of exposed surfaces. At angles above $75^{\circ}$ fragments have high tendency of ricocheting, denting or scarring the surface of a target, and many penetration models are not applicable [9].

Minimal value of fragment impact velocity is:

$$
v_{\mathrm{f}, \min }=\sum \Delta v_{\mathrm{i}}
$$

where appropriate $i^{\text {th }}$ parts of a missile are considered only. Results are calculated numerically until $v_{\mathrm{f}, \min }=v_{\mathrm{f}, 1}$ criterion is met. The results are presented in Figures 8 and $9\left(v_{\mathrm{f}, \min }^{\text {: }}\right.$ : frontally, red lines; $v$ " $_{\text {f.min }}$ : laterally, olive green lines) for different diameters of steel spherical fragments $d_{\mathrm{f}}(2 \mathrm{~mm}$ : doted lines; $3 \mathrm{~mm}$ : short dash lines; $4 \mathrm{~mm}$ : long dash lines; $5 \mathrm{~mm}$ : solid lines).

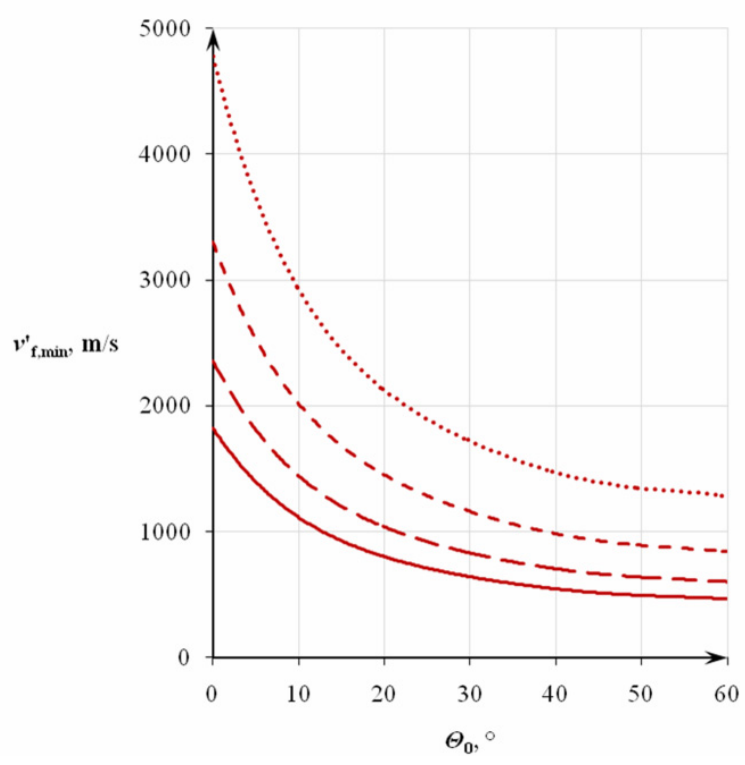




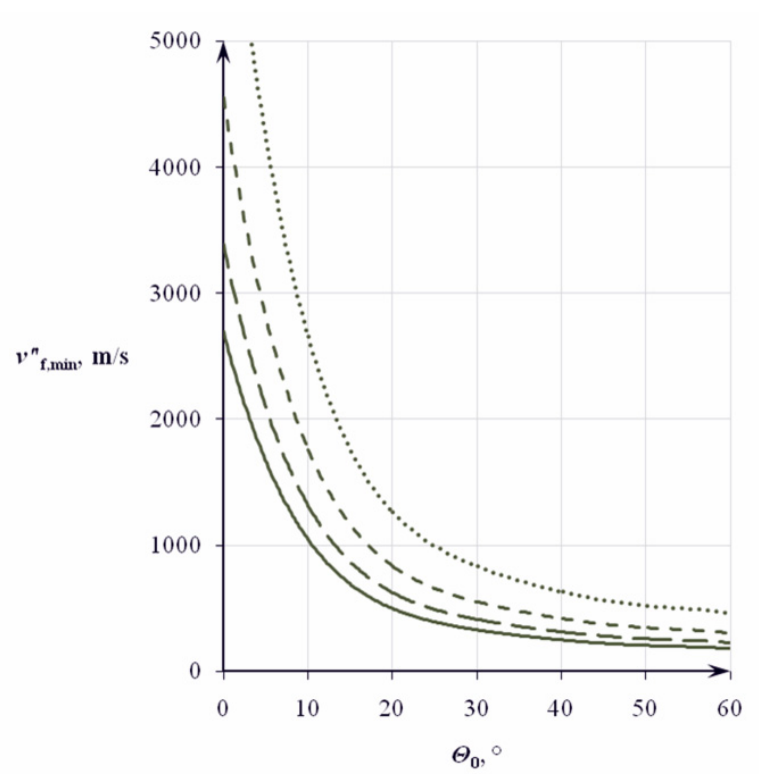

Figure 8. Minimal impact velocities of fragments for penetration of RPGtype warhead
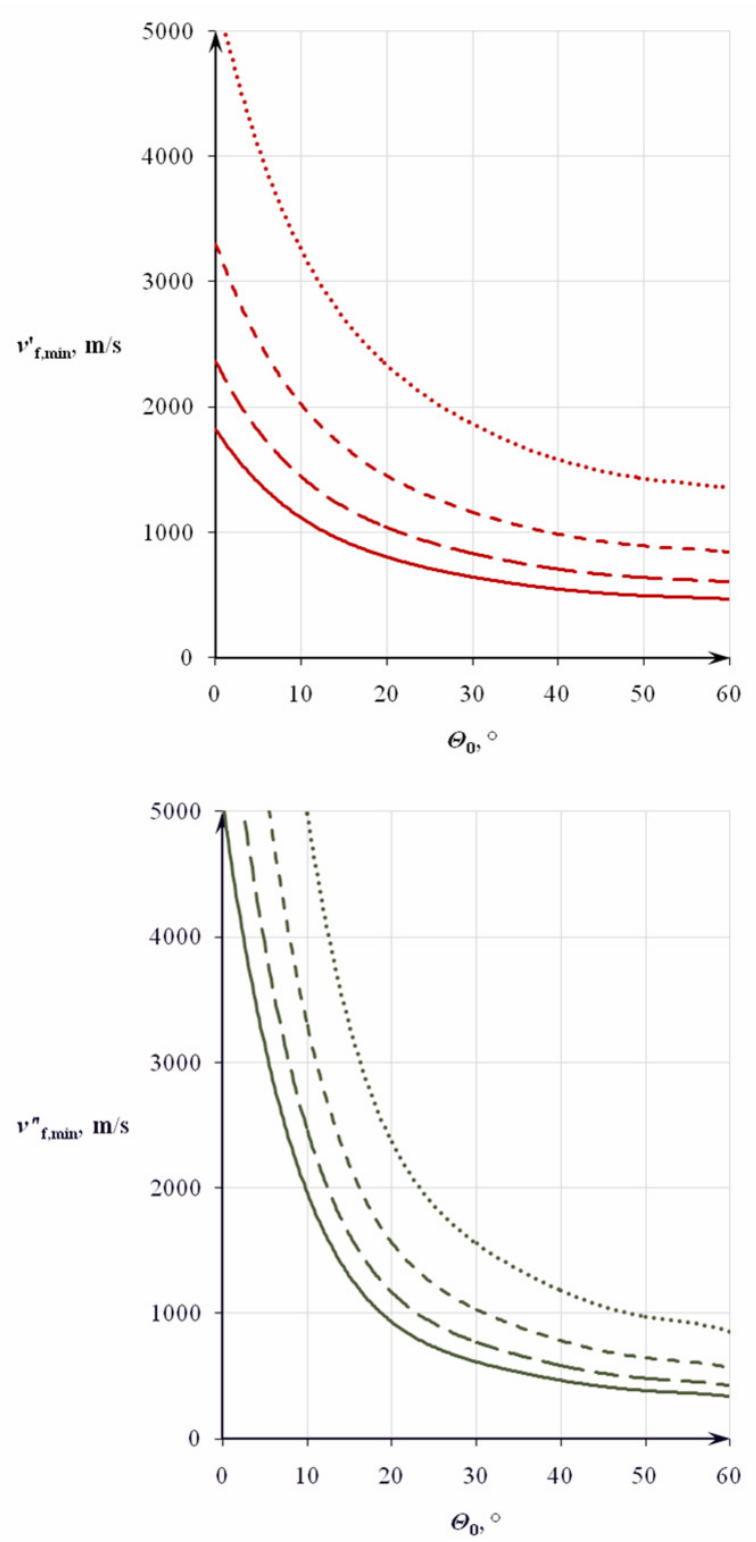

Figure 9. Minimal impact velocities of fragments for penetration of ATGMtype warhead
Table 4. Empirical coefficients in "Thor" equations [9-12]

\begin{tabular}{|c|c|c|}
\hline Coefficient & Copper & Alloy 2024-T3 \\
\hline \hline$c$ & 2.785 & 7.047 \\
\hline$\alpha$ & 0.678 & 1.029 \\
\hline$\beta$ & -0.730 & -1.072 \\
\hline$\gamma$ & 0.846 & 1.251 \\
\hline$\lambda$ & 0.802 & -0.139 \\
\hline
\end{tabular}

\section{Minimal performances of high-explosive interceptor projectiles}

Fragment number density needed for reliable hit of an incoming projectile was determined according to Equation 4 and values of exposed areas of considered AT projectiles (Tables 1 and 2). Minimal fragment number densities for considered AT projectiles for different interception angles are presented in Table 5. According to the size of fragment zone, these results can be used to indicate minimal number of fragments that interceptor projectile should have.

Table 5. Minimal fragment number density

\begin{tabular}{|c|c|c|}
\hline AT weapon system & Warhead & Missile \\
\hline \hline M72 LAW & \multicolumn{3}{|c|}{$87-293$} \\
\hline RPG-7 & \multicolumn{3}{|c|}{$43-177$} \\
\hline C90-CR-RB & $30-84$ & $11-70$ \\
\hline 9K11 "Malyutka" & $12-65$ & $8-62$ \\
\hline FGM-148 "Javelin" & \multicolumn{2}{|c|}{49} \\
\hline
\end{tabular}

The results of minimal impact velocity are needed next (Figures 8 and 9), since fragments must be capable of damaging the incoming AT projectile. Threshold values of minimal impact velocities are presented in Table 6.

Table 5. Minimal impact velocity of fragments

\begin{tabular}{||c|c|c|c|c||}
\hline \multirow{2}{*}{$\begin{array}{c}\text { Fragment di- } \\
\text { ameter } d_{\mathrm{f}}, \mathrm{mm}\end{array}$} & \multicolumn{2}{|c|}{ RPG-type } & \multicolumn{2}{c|}{ ATGM-type } \\
\cline { 2 - 5 } & \begin{tabular}{c} 
Minimal fragment impact velocity, $\mathrm{m} / \mathrm{s}$ \\
\cline { 2 - 5 } \\
\cline { 2 - 5 } \\
$v_{\mathrm{f}, \mathrm{min}}^{\prime}$
\end{tabular} & $\begin{array}{c}\text { laterally, } \\
v_{\mathrm{f}, \mathrm{min}}\end{array}$ & $\begin{array}{c}\text { frontally, } \\
v_{\mathrm{f}, \mathrm{min}}^{\prime}\end{array}$ & $\begin{array}{c}\text { laterally, } \\
v_{\mathrm{f}, \mathrm{min}}^{\prime}\end{array}$ \\
\hline \hline 2 & $1283-4776$ & $456-2661$ & $1349-5322$ & $853-4978$ \\
\hline 3 & $796-2999$ & $302-1763$ & $840-3304$ & $565-3296$ \\
\hline 4 & $569-2162$ & $226-1316$ & $601-2361$ & $422-2460$ \\
\hline 5 & $439-1678$ & $179-1048$ & $465-1822$ & $336-1961$ \\
\hline
\end{tabular}

Since velocity of fragments $v_{\mathrm{f}}$ can be reliably calculated using various propulsion models based on correlation between fragment velocity and fragment and explosive charge mass ratio [7-16]. Total mass of propelled metal directly depends on the size and minimal number of fragments, so minimal mass of the explosive charge can be determined according to the minimal fragment velocity.

\section{Conclusions}

Capabilities of an interceptor projectile with fragmentation effect have been assessed according to the vulnerability of various AT projectiles with a HEAT warhead. The lowest vulnerability have small caliber projectiles, thus with small exposed area, at small interception angles. An interception angle has very significant effect on the AT projectile's exposed area also. For $0^{\circ}$ interception angle, approximately 300 fragments per $\mathrm{m}^{2}$ are needed for one hit in the frontal surface of 64-72 mm AT rockets used in modern individual light AT weapon systems with 150-300 m effective range. 
Due to their size, larger caliber AT rockets and ATGMs are more vulnerable (f. e. for $85-90 \mathrm{~mm}$ and ATGM warheads at least 160-180 and below 100 fragments per $\mathrm{m}^{2}$ are needed, respectively).

Since the design criteria of contemporary HEAT warheads are oriented towards minimal mass and maximal effect, their outer parts are made of thin metals or polymer materials. If explosive charge to fragment mass ratio is in the 2-3 range, and using explosives with the largest explosion energy output (Gurney velocity above $2800 \mathrm{~m} / \mathrm{s}$ ), initial velocities of fragments are expected in $2000-2500 \mathrm{~m} / \mathrm{s}$ range. Even when combined with velocities of interceptor and incoming projectiles, practical velocity of fragments will be bellow $3000 \mathrm{~m} / \mathrm{s}$. Results of this research show that large steel spherical fragments $\left(d_{\mathrm{f}} \geq 3 \mathrm{~mm}\right)$ are expected to perforate all considered frontal layers of both types of HEAT warheads at nearly all interception angles. Similar conclusions can be made for perforation of warhead body too. It should be noted, that smaller fragments are also having sharper decrease of velocity due to an aerodynamic drag.

Increase in interception angle causes very significant increase of exposed area. Approximately $50 \%$ of fragments are needed for the same AT projectiles at 20-25 ${ }^{\circ}$ interception angles. Multiple hits into the AT projectile are expected for the same fragment number density, increasing the possibility of its explosion or function failure. Since impact angle is decreased with an increase of interception angle, significantly slower fragments are needed for reliable perforation of warhead parts. For larger fragments, minimal impact velocity is mostly below $1200 \mathrm{~m} / \mathrm{s}$ for interception angles above $15^{\circ}$ (Figures 8 and 9). Stronger effect of air shock wave is expected also. Since this case of interception is favorable, it should be thoroughly considered for development of an APS.

Furthermore, for frontally impacting fragments, size of contact subsystems of a fuze can be the most decisive vulnerability factor. That is especially evident for ATGMs, where contact subsystems are covering the largest part of frontal surfaces. For example, all models of ATGMs for "Malyutka" have piezoelectric fuze system that is activated by an impact to any part of a windshield. In such cases, smaller fragments can be used for multiple hits of an AT projectile, penetrating into its frontal parts, thus reliably activating fuze system or damaging guidance subsystems.

\section{References}

[1] GENERAL DYNAMICS ORDNANCE AND TACTICAL SYSTEMS: Iron Fist Light Decoupled Active Protection System, Product Catalogue, https://www.gd-ots.com/protection-systems/active- protection-systems/iron-fist-light-active-protection-system/, accessed May 15, 2021.

[2] HAUG,D., WAGNER,H.J.: Active hardkill protection systems Analysis and evaluation of different system concepts, Strategie \& Technik. Report-Verlag, Frankfurt am Main. Autumn, 2009.

[3] BAJIĆ,Z., BOGDANOV,J., JEREMIĆ R.; Blast effects evaluation using TNT equivalent, Scientific Technical Review. 59(3-4). pp. 50-53. 2009.

[4] LAZAREVIĆ,M., NEDIĆ,B., BOGDANOV,J., ĐURIĆ,S.: Determination of critical distance in the procedure of explosive welding, Military Technical Courier, 68(4), pp. 823-844, 2020.

[5] ZAKER,T. A.: Fragment and Debris Hazards, Technical Paper No. 12, Department of Defense Safety Board, Washington D. C., 1975.

[6] STAMATOVIĆ,A.: Design of Projectiles (in Serbian: Konstruisanje projektila), Ivexy, Belgrade, 1995.

[7] HELD,M.: Fragmentation warheads, in Tactical Missile Warheads (edited by CARLEONE J.). Vol. 155, pp. 387-464, AIAA Inc., Washington D. C., 1993.

[8] LIXIN,Q., MING,Q., YU,W., YONGQING,Z., DAOJIAN,J.: Dense fragment generator, Propellants. Explosives Pyrotechnics, 27. pp. 267$278,2002$.

[9] ZOOK,J.: An Analytical Model of Kinetic Energy Projectile/Fragment Penetration, Memorandum Report No. 2797, USA Ballistic Research Laboratory, Aberdeen Proving Ground, Maryland, 1977.

[10] DHOTE,K. D., MURTHY,K. P. S., RAJAN,K. M., SUCHEENDRAN,M. M.: Directional warhead design methodology for tailored fragment beam, Central European Journal of Energetic Materials, 12(4), pp. 637-649, 2015.

[11] DHOTE,K. D., MURTHY,K.P.S., RAJAN,K.M., SUCHEENDRAN,M.M.: Statistics of fragment dispersion by explosion in a fragment generator warhead, Central European Journal of Energetic Materials, 13(1), pp. 183-197, 2016.

[12] WANG,J., WANG,Y.-C., ZHU,S.-Q., REN,W.-H., NIU,T.-L.: Improvement and simulation of THOR formula with yaw angle, Journal of Engineering Science and Technology Review, 7(2), pp. 106-112, 2014.

[13] ODINCOV,V.A., ORLENKO,L.P.: Propulsion of objects using detonation products (in Russian: Метание тел продуктами детонации), in Explosion Physics (in Russian: Физика взрыва), (edited by ORLENKO L. P.), Nauka, Moscow, 2004.

[14] KESHAVARZ,M.H., SEMNANI,A.: The simplest method for calculating energy output and Gurney velocity of explosives, Journal of Hazardous Materials, A131, pp. 1-5, 2006.

[15] FREM,D.: A simple relationship for the calculation of the Gurney velocity of high explosives using the $B K W$ thermochemical code, Journal of Energetic Materials, 33, pp. 140-144, 2015.

[16] MATHIEU,D.: Prediction of Gurney parameters based on an analytic description of the expanding products, Journal of Energetic Materials, 33, pp. 102-115, 2015.

[17] FM 3-22.27 Javelin - Close Combat Missile System, Medium, Headquarters, Department of the Army, Washington D. C., 2008.

\section{Potrebne mogućnosti razornog projektila za sistem aktivne zaštite}

\begin{abstract}
Prikazan je koncept sistema aktivne zaštite borbenih vozila, čija se zaštitna funkcija zasniva zaštitnom projektilu, koji vrši presretanje i parčadno dejstvo po protivoklopnom projektilu. Proces razvoja i osobine sistema aktivne zaštite vrlo značajno zavise od osobina i mogućnosti zaštitnog projektila. Razmatran je zaštitni projektil koji ostvaruje čeono usmereno parčadno dejstvo pomoću čeličnih kuglica. Izvršeno je istraživanje osobina konstrukcije savremenih protivoklopnih raketa s ciljem definisanja potrebnih mogućnosti zaštitnog projektila. Analizirana je ranjivost protivoklopnih raketa na osnovu dimenzija i konstrukcije njihovih podsistema. Pri određivanju parametara ranjivosti korišćeni su reprezentativni modeli različitih vrsta protivoklopnih raketa. Prikazani su rezultati minimalne gustine parčadnog polja i minimalne udarne brzine parčadi, na osnovu kojih su izvedeni odgovarajući zaključci.
\end{abstract}

